\title{
Getting To Know Our Less Common Birds
}

\author{
by Margaret Belcher and Maureen' Rever, Regina
}

Saskatchewan birders are always thrilled when birds better known in other areas make their appearance in this province. But it is often difficult for the inexperienced birder to be sure of the identity of the stragglers he is seeing for the first time. For this reason, most of us travelling outside the province are eager to get to know the birds that may one rare day come to feed in our own backyard or flit through the shrubbery in a wave of spring migrants. This was the way we felt when we set dut in late May of this year on a two 'weeks' trip into the mid-western states. Although our main purpose was ito collect Astragalus, we looked forward to doing some bird watching along the way, and long before we left Regina we were checking in Peterson's field guide the western species that we hoped to become better acquainted with.

Any species classed as a "straggler" on the Saskatchewan field check-list deserved special attention, but there were many other birds of almost equal interest to us simply because we had never seen them ourselves. Some few species that come to us only as migrants we would perhaps see on their breeding grounds. We hoped that we would find dippers and harlequin ducks on the mountain streams and would learn the warbled song of the Townsend's solitaire which has endeared itself to Regina bird watchers by its unusual winter appearances in the city. We would look for the beautiful Steller's jay of the Lansdowne painting used for the Audubon Society's Christmas card, and for the piñon jay in the piñon (although we weren't too sure at that point what "piñon" was!). We would perhaps add to our list the tiniest of the hummingbirds, the calliope, and the beautiful violetgreen swallow. We would watch for the western tanager that was reported in Regina just after the Birds of Regina went to press, and for the cinnamon teal which we had never been on hand to see during its several appearances in the Regina area.
We left Regina by car on May 29 and before the day was over we were already viewing a changing scene. Going south on Highway \#6 we noted how two birds of the dry prairiesthe chestnut-collared longspur and lark bunting-became more abundant as we neared the United States border. This helped to prepare us for the great numbers of lark buntings that seemed to us the most striking feature of bird life on the Montana plains. Another interesting observation of adaptation to this treeless plains habitat was the crow's nest on a telephone pole that we saw along the highway before we left Saskatchewan. This observation took on added interest later when we read Bob Nero's comment in the Blue Jay (September, 1962) on a similar nest site at Boharm, Saskatchewan.

We stopped for our first "coffee break" beside a slough over which three kinds of swallows were skimming-cliff, bank, and rough-winged, the latter quite uncommon at Regina and therefore getting special attention as we tried to follow them with binoculars. Then for our picnic dinner we drove off the highway into the rolling hills of the Missouri River Valley near Culbertson and found a little draw with trees and shrubs near a stock corral. Although it threatened to rain, this spot was a delight. At the corral a pair of red-headed woodpeckers kept moving elusively away from the camera, but were finally photographed. This woodpecker has been reported on several occasions this year in southern Saskatchewan, interestingly enough on dates close to that of our observation of the two woodpeckers on territory in Mcntana. A later record for June 27, 1962, of a male bird that Bob Symons watched for an hour and a half at Pelican Point, Last Mountain Lake, raises the question of the status of the bird-was it a breeding bird or summer wanderer?

Beyond the corral were mountain bluebirds, rufous-sided towhees and lazuli buntings, for which the grove of trees provided nesting territory. 


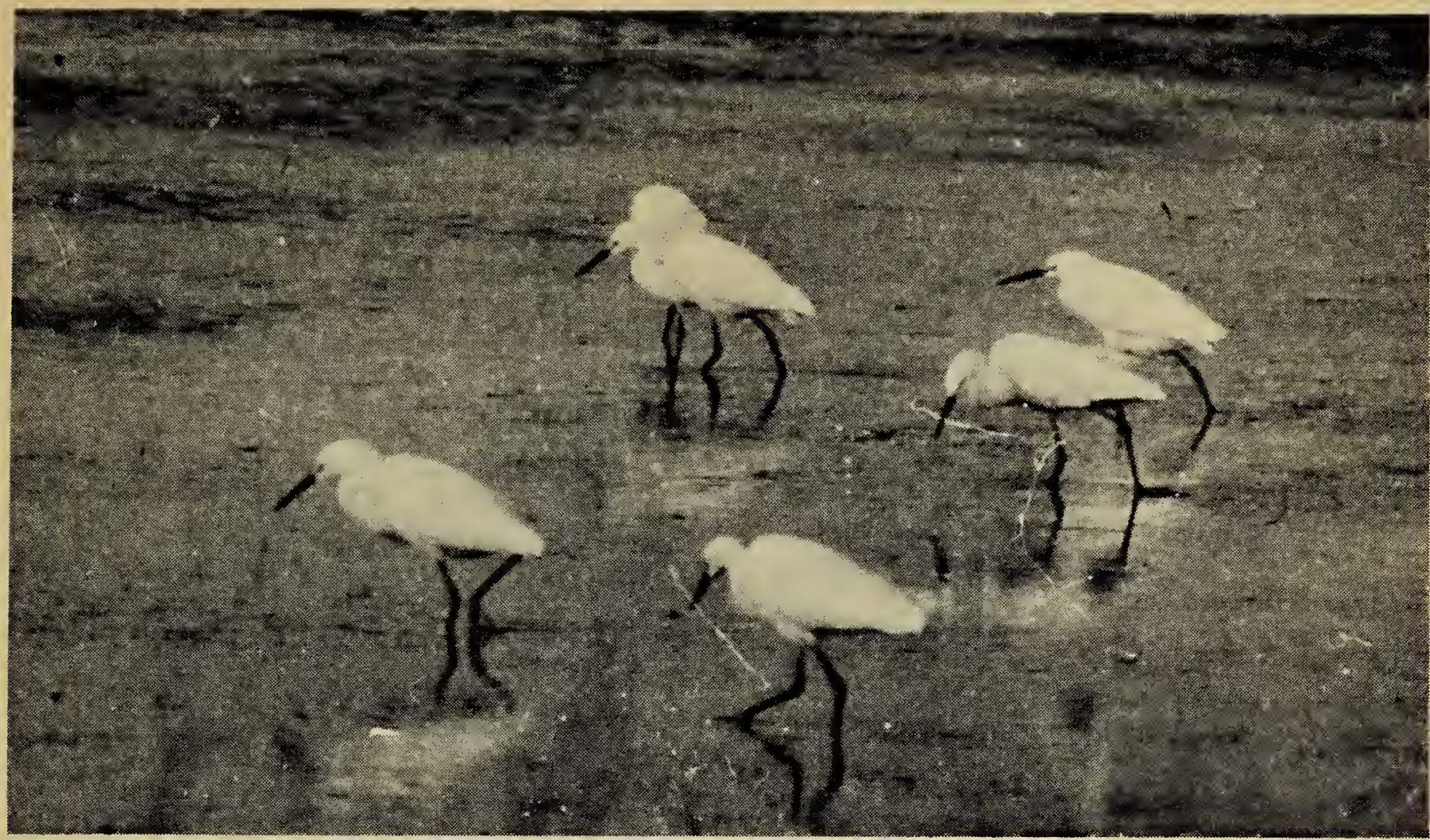

Snowy Egrets at the Bear River Refuge.

Photo by M. Rever

Indeed, this attractive little bit of bird habitat came very clearly to mind later in the summer when an expedition with George Ledingham into the "dirt hills" of Avonlea, Saskatchewan, on July 20 discovered lazuli buntings in an almost identical setting. The rolling hills at Avonlea constituted typical Missouri coteau countryside with 'occasional bluffs and sheltered coulees. Two male buntings were seen, about three miles apart, moving back and forth from clumps of aspen and box elder, with shrubs like willow, buffalo berry, snowberry and wild rose. This setting, and the lovely colours of the male bunting, recalled vividly our introduction to the lazulis in Montana.

It is a commonplace that habitat usually provides the key to the birds to be found in any given spot. This idea is developed by Olin S. Pettingill, $\mathrm{Jr}$, in his guides to bird finding. Even though our bird watching was very casual, we made good use of his Guide to bird finding west of the Mississippi (1953). In the Medicine Lake National Wildlife Refuge in Montana, we watched from the shoulder of the highway the characteristic species of a prairie marsh, and again in northern Utah we looked for marsh birds in the deservedly famous Bear River Migratory Bird Refuge. There were no new species for us at the Medicine Lake refuge, but the Bear River marshes introduced us to birds we had never seen before which we shall now be prepared to look for in similar habitat in Saskatchewan. Seeing so many black-necked stilts showed us that this bird, still a hypothetical species on the Saskatchewan list, is so definitely marked that any experienced observer could identify it with assurance. And if a small white heron with black legs ever lifts its curious yellow feet out of the shallow waters of the Qu'Appelle River flats, we shall not fail to recognize it as a snowy egret!

The Bear River Migratory Bird Refuge on the delta of the Bear River where it empties into Great Salt Lake is one of the outstanding waterfowl areas in North America. It was established in 1928 to safeguard waterfowl against losses from botulism, and the 64,000 acres of the refuge are still maintained for the protection of nesting waterfowl and the great flocks of migrants that rest there in the spring and fall. We thought with envy of the A.O.U. birders who would be visiting the refuge in August when the migrant waders arrive in thousands, but even in early June with only resident species at the refuge, a visit there is a thrill for anyone who has never seen such birds as the snowy plover, black-necked stilt, 


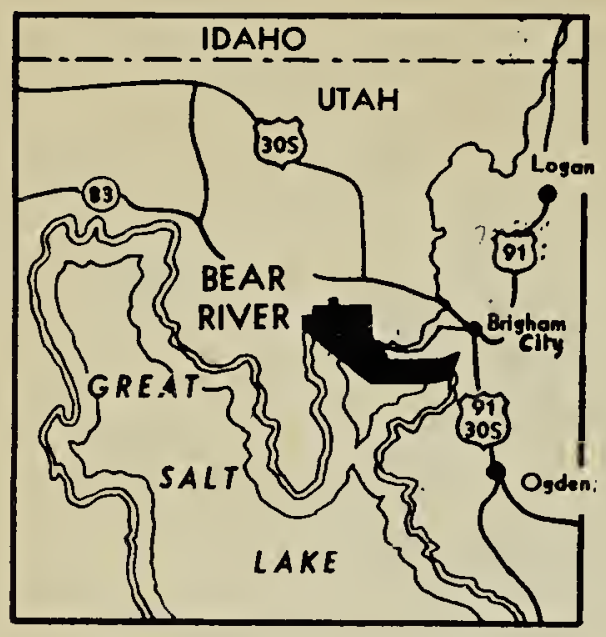

Bear River Refuge

snowy egret, white-faced ibis and cinnamon teal. Since the blue wing is the' familiar teal of our Saskatchewan pothhole country, we were amazed to find the cinnamon teal apparently much more common here, as we travelled the 12 miles of dykes enclosing : one of the units in which the water from the Bear River is impounded and distributed. The teeming life of the refuge we viewed again this fall when Allan D. Cruickshank brought his Audubon Screen Tour film of the Bear River to Regina.

One of the attractions for visitors to the Bear River refuge are the migrating swans, which of course we did not see. However, we did have a very good view of a pair of nesting Trumpeters as we came into Idaho from West Yellowstone, at Swan Lake - to which the Trumpeters have given their name.

Birds of the sagebrush country interested us because we felt that these species could be looked for also in the dry prairie ranchlands of southwestern Saskatchewan and along the South Saskatchewan River above the "elbow." Our first Brewer's sparrow, on a sage-covered hillside sloping down to the Soda Butte Creek in Yellowstone Park, we had almost dismissed as a pale-colored Clay-colored when we realized that the latter was not on the list for the park. By the following day, however, we had become quite familiar with the Brewer's sparrow through its song which we heard so often in sagebrush pastures fringing the sand dunes where we were hunting for Astragalus near St. Anthony, Idaho. There we also found sage thrashers, our attention having been called to them too by their song. These are birds that are well enough known in Sastaatchewan, but only locally. Bob Nero called the Brewer's sparrow "common" in the Val Marie district this summer when he was visiting the prairie dog colonies, and there it has the added interest of sharing the same range as the claycolored sparrow which it resembles in appearance, though not in song.

On a sage-covered slope of Malad Summit in southeastern Idaho, interspersed with shrubs and some larger trees, we tracked down two greentailed towhees on June 2, and were especially pleased to find two nests with three and four eggs, in low sagebrush. The distribution of this bird is known to be the mountain districts of the western states, and yet a male bird appeared (and was collected to prove it) in a wooded coulee on a farm on the Regina plains in June, 1929 (Birds of Regina, 1961). This goes to show that the bird watcher. is justified in keeping eyes and ears open for unexpected strangers!

In the evergreen forests of the higher mountains we saw the Clark's nutcracker which many Saskatchewan birders have seen in the Canadian Rockies and which has been reported from the Cypress Hills. Also on a mountain side, up the Habble Creek near Springville, Utah, our first western tanager called its dry "pic-tic" note from the top of a very tall narrow-leaved poplar. We did not both see the bird then, but we had good views later on an early morning birding expedition on IMoscow Mountain, in Idaho. We ourselves have never seen the western tanager in Saskatchewan, but it is described as a "rather rare summer resident" at Nipawin (C. Stuart Houston and Maurice G. Street, The Birds of the Saskatchewan River, 1959). In the observation of three birds at Cumberland House, June 18, 1958, which is given as the easternmost record for this latitude (ibid.), it interests us that the birds seen by Stuart and Mary Houston, T. E. Larsen, and Russell Robertson, were-like our first bird-in high poplars.

The bird hike on Moscow Mountain also gave us our first view of the calliope hummingbind, a tiny but showy male with the curious red rays 
across his throat by which we were able to identify him. Earlier, on $\mathrm{Mt}$. Washburn in Yellowstone Park, we had come upon the varied thrush and Audubon's warbler on a tramp up a mountain road, two species that we have actually seen in Saskatchewan; but the striking Steller's jay along the wooded slopes of the rugged Price Canyon was a "first."

We saw our first black-headed grosbeaks on the higher slopes, too, but we asscciated them with a shrubby type of cover rather than with the heights of Malad Summit. This bird, too, appears casually in Saskatchewan and the most recent record we know of is Bob Symon's observation at Pelican Point - although Symons searched diligently for a nest, he found none, but up to three young were seen with the adults several times from July to September, and two young were seen for a last time on Oct. 13. On our trip, the Bullock's oriole, another species occasionally seen in Saskatchewan, was present near farms and homes, as the Baltimore oriole would be with us.

When we saw species like the dipper or the varied thrush which are still listed as hypothethical for Saskatchewan because sight records have not been backed up by specimens or authentic photographs, we felt reasonably sure that it was only a matter of time before they would be added to the official list. The real fun comes in speculating on which ones of the birds that you are seeing for the first time outside the province will turn up some day for the first time in Saskatchewan. Stuart Houston tells us to look for house finches, and certainly we found them common in many kinds of places in Idaho and Utah. David Chandler of Masefield, we think, would bet on the violet-green swallow which he feels he may have seen this spring with other migrant swallows. This seems a real possibility, since the violetgreen swallows have nested in the Red Deer area of Alberta (W. R. Salt and A. L. Wilk, Birds of Alberta, 1958.) Why, too, should we not see the Barrow's goldeneye that nests in the mountains and foothills of Alberta, at least in migration, swimming on a shallow slough in the Cypress Hills, let us say, as we saw them in Yellowstone Park?

Many of the birds we saw here were new to us, but some of our most enjoyable observations were of familiar birds seen in a new perspective. Cliff swallows, which have to resort to building under bridges on our prairies, were studied with renewed interest at natural nesting sites like the rock wall of Lamar Canyon. Occasionally, too, we were

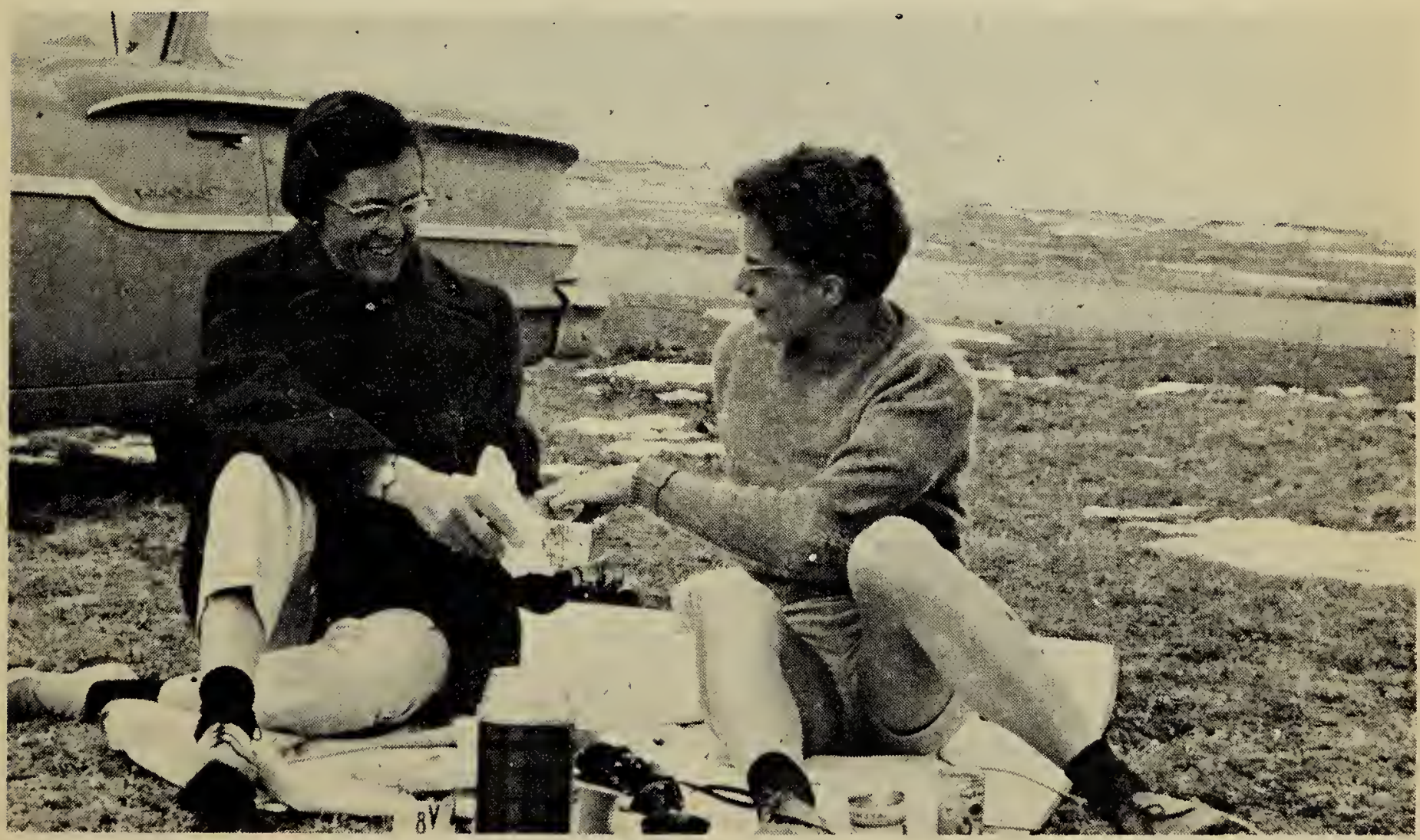


introduced to the breeding habitat or behaviour of birds which we have only in migration. Nothing charmed us more than to hear the aerial flight song of water pipits as we ate our lunch at 10,800 feet in the Bear Tooth Pass on an alpine meadow from which the snow had just melted to reveal the first clumps of mountain marigold, carpet pink and alpine forget-me-not.

Driving on over the pass from that alpine meadow our view was often cut off by the high snowbanks, for we were on the road the first day that it was open to traffic. One bank along the road, we later learned, measured $29^{\prime} 6^{\prime \prime}$, and yet everywhere over the snow the horned larks and pipits rose in song. The pink Chev, with its nose nudging a Highways Department patrol truck, was only travelling five or ten miles an hour, so we had time to watch them, and to get a good look at a black rosy finch which thrilled us by perching briefly on the highway railing.

To do our expedition justice, it should be said that it was more productive botanically than bird-wise. However, the two weeks of plant collecting gave us opportunities to watch for new birds; that is, when our eyes weren't glued to the ground looking for Astragalus! In addition to the Astragalus collections, we brought back a lively interest in the birds less commonly seen in Saskatchewan.

\section{Sixth Annual May Day Count Saskatoon Natural History Society, May 26, 1962}

As an experiment the Saskatoon Natural Society decided this year to record the birds seen within a 25mile radius of the city. Because the area was so extensive, it was impossible to make a count of individuals. Instead, the circle was divided into segments, and a record cf occurrence kept within each segment. The 24 observers were divided into 5 parties. Observations extended from 4.30 a.m. to 9:00 p.m. Temperatures ranged from a low of $47^{\circ}$ at 5:00 a.m. to a high of $78^{\circ}$ at $5: 30$ p.m. Winds were light; the sky varied from clear to slightly cloudy. 127 species were identified, 27 more than last year, and 15 more than the previous record of 112 set in 1959 (within a $71 / 2$ mile radius).

SPECIES LIST: Horned Grebe, Eared Grebe, Western Grebe, Pied-billed Grebe, Great Blue Heron, Black-crowned Night Heron, American Bittern, Mallard, Gadwall, Pintail. Greenwinged Teal. Blue-winged Teal, Americon Widgeon, Shoveler, RedheaJ, Ring-necked Duck, Canvasback, Lesser Scaup, Bufflehear, Ruddy Duck, Cooper's Howk, Red-tailed Hawk, Swainson's Hawk, Marsh Hawk, Peregrine Falcon, Pigeon Hawk, Sparrow Hawk, Sharptoiled Grouse, Ring-necked Pheasant, Groy Partridge, Sandhill Crane, Sora, American Coot, Semipalmated Plover, Killdeer, Golden Plover, Black-bellied Plover, Ruddy Turnstone,
Long-billed Curlew, Upland Plover, Spotted Sandpiper, Willet, Greater Yellawlegs, Lesser Yellowlegs, Knot, Pectoral Sandpiper, Whiterumped Sandpiper, Baird's Sandpiper, Least Sandpiper, Dunlin; Stilt Sandpiper, Semipalmated Sondpiper, Marbled Godwit, Sanderling, Avocet, Wilson's Phalarope, Northern Phalorope, California Gull, Ring-billed Gull, Franklin's Gull, Common Tern, Black Tern, Rock Dove, Mourning Dove, Great Horned Owl, Burrowing Owl, Yellow-shofted Flicker, Hairy Woodpecker, Downy Woodpecker, Eastern Kingbird, Western Kingbird, Eostern Phoebe, Least Flycatcher, Horned Lark, Tree Swallow, Bank Swallow, Barn Swallow, Cliff Swallow, Blue Jay, Black-billed Magpie, Common Crow, Black-capped Chickadee, Red-breasted Nuthatch, House Wren, Cotbird, Brown Throsher, Robin, Swainson's Thrush, Veery, Mountain Bluebird, Water Pipit, Sprague's Pipit, Cedar Waxwing, Loggerhead Shrike, Starling, Warbling Vireo, Black-and-white Warbler, Tennessee Worbler, Orange-crowned Warbler, Yellow Warbler, Blackpoll Warbler, Yellowthroat, American Redstart, House Sparrow, Bobolink, Western Meadowlark, Yellow-headed Blackbird, Red-winged Blackbird, Baltimore Oriole, Brewer's Blackbird, Common Grackle, Brownheaded Cowbird, Rose-breasted Grosbeak, American Goldfinch, Rufous-sided Towhee, Savannah Sparrow, Baird's Sporrow, Vesper Sparrow, Lark Sparrow, Chipping Sparrow, Clay-colored Sparrow, Harris' Sparrow, Whitethroated Sparrow, Lincoln's. Sparrow, Song Sparrow, Lapland Longspur, Chestnut-collared Longspur. Compiler: Frank Roy, Saskatoon. . 